\title{
En sprek mann med feber og vondt i lårene
}

\author{
Vi presenterer et typisk forløp for en infeksjonssykdom som ses sjelden \\ i Norge. Kasuistikken illustrerer at både anamnesen og god kjennskap \\ til uvanlige infeksjonssykdommer kan være avgjørende for å stille riktig \\ diagnose.
}

Engelsk oversettelse på www.tidsskriftet.no

Se kommentar side 670

\author{
Marius Myrstad \\ marius.myrstad@diakonsyk.no \\ Kiarash Tazmini \\ Knut Henrik Spæren \\ Aira Bucher \\ Medisinsk avdeling \\ Diakonhjemmet Sykehus
}

En sprek mann i 70-årene kom til akuttmottaket med ambulanse på grunn av sterke smerter i begge lår. Smertene hadde debutert fem dager tidligere, mens mannen var $i$ fjellet på jakt. Smertene startet som diffus verking i begge lår og ble først oppfattet som stølhet etter lang marsj i fjellet. Smertene tiltok $i$ intensitet, og neste dag fikk mannen feber og hyppig vannlating med små tømninger. Tredje dag fikk han diaré uten magesmerter. Lårsmertene vedvarte, økte $i$ intensitet de neste dagene og var til slutt så plagsomme at mannen ringte etter ambulanse fordi han hadde problemer med å gå. Han var fra før usedvanlig sprek og drev med roing og annen konkurranseidrett. Før han dro til fjells, hadde han nettopp returnert fra et ti dagers opphold i Sør-Frankrike, hvor han blant annet hadde rodd på en elv. Mannen hadde ikke vært syk tidligere, brukte ingen medisiner og hadde ikke vært hos lege på mange år.

Da pasienten ble undersøkt $i$ akuttmottaket var han medtatt. Temperaturen målt i øret var $39,0^{\circ} \mathrm{C}$, puls 80 , blodtrykk $140 / 90$ og EKG viste sinusrytme. Pasienten var ikke palpasjonsøm i lårmuskulaturen, men fikk uttalte smerter $i$ lårene ved forsøk på bevegelse. Det var palpable og sidelike pulser både i lysker og distalt på underekstremitetene. Hudfarge og -temperatur var upåfallende på begge sider. Det var ingen hevelse i beina. På høyre albue fant man et sår uten infeksjonstegn. Mannen fortalte at han under turen til Sør-Frankrike hadde falt og slått høyre albue. Etter fallet hadde han hatt en stor kul på albuen, som etter noen dager spontant tømte seg for blank væske. For øvrig var den somatiske og nevrologiske undersøkelsen upåfallende.
Pasienten ble innlagt med en uavklart tilstand, hvor hovedsymptomet var kraftige smerter i begge lår ved fors $ø \mathrm{k}$ på bevegelse. Stølhet er ikke uvanlig de første dagene etter lang marsj i fjellet. Men i dette tilfellet økte plagene $i$ intensitet over flere dager og var til slutt så uttalte at de ikke kunne forklares av den fysiske anstrengelsen. Dessuten hadde pasienten feber, noe som i første omgang fikk en til å lete etter et fokus for infeksjon. Tumor over høyre olecranon kunne ha representert en bursitt og således et utgangspunkt for infeksjon. Pollakisuri kunne være et symptom på urinveisinfeksjon. Pasienten hadde diaré, men ikke andre symptomer fra gastrointestinalkanalen, og heller ingen andre spesifikke symptomer som ga holdepunkter for infeksjonsfokus.

Orienterende blodprøver viste trombocytter $32\left(139-45010^{9} / l\right)$, senkning $46(2-10 \mathrm{~mm} /$ time), CRP $355(0-10 \mathrm{mg} / \mathrm{l})$, natrium 127 (137-145 mmol/l), kalium 3,2 (3,5-5,0 mmol/l), kreatinin 257 (50-90 $\mu \mathrm{mol} / \mathrm{ll})$, estimert glomerulær filtrasjonshastighet (eGFR) 21, urinstoff 28,7 (3,0-8,0 mmol/l), ASAT 233 (15-35 U/l), ALAT 146 (10-45 U/l), gammaGT 83 (10-75 U/l), alkaliske fosfataser 220 (35-105 U/l), CK 539 (35-210 U/l) og laktatdehydrogenase (LD) 380 (115-255). Øvrige verdier var innenfor referanseområdene. Arteriell blodprøve viste $\mathrm{pH} 7,53(7,35-7,45)$, $\mathrm{pO}_{2}$ 8,1 (11,0-14,0 kPa) $\mathrm{pCO}_{2} 3,8 \quad(4,7-6,0$ $\mathrm{kPa}$ og $\mathrm{O}_{2}$-metning 93 (94-99\%), ellers normale verdier. Røntgen thorax var normal. Urinstiks viste hvite $2+$, albumin $1+$, blod $3+$, nitritt og glukose var negativ. Ved urinmikroskopi var det moderate mengder røde og hvite blodceller og plateepitel.

Det var påfallende at nesten alle blodprøver var unormale. Høy CRP og senkning styrket infeksjonsmistanken. Nyresvikt og forhøyede leverprøver tydet på at sykdommen affiserte flere organer, slik man kan se ved sepsis. Hyponatremi og hypokalemi kunne forklares ved gastrointestinalt tap ved diaré eller renalt tap. Sterke smerter kan stimulere
ADH-sekresjon, som kan gi hyponatremi via en fortynningseffekt. Trombocytopeni kunne være forårsaket av beinmargsdepresjon på grunn av infeksjon. Moderat forhøyet CK, LD og transaminaser passet med muskelsykdom, men man hadde fortsatt ingen sikker forklaring på mannens smerter i lårene.

Tilstanden ble $i$ akuttmottaket vurdert som en bakteriell infeksjon med ukjent fokus. Etter at blodkulturer og urin-og avføringsprøve til dyrking var tatt, ble det startet behandling med ceftriakson $2 g \times 1$, klare væsker intravenøst og korreksjon av elektrolyttforstyrrelsene. Pasienten ble afebril i løpet av første døgn, for øvrig endret tilstanden seg lite første to døgn etter innleggelse. Tredje dag var lårsmertene mindre uttalte, avføringen mer formet og allmenntilstanden klart bedret. CRP hadde falt til 90. Etter råd fra avdelingens infeksjonsleger ble det tatt blodprøve til hantavirus-og leptospiroseserologi.

Nephropathia epidemica var aktuell som differensialdiagnose fordi pasienten nylig hadde vært til fjells. Feber, trombocytopeni og nyresvikt kunne passe med denne sykdommen, som skyldes infeksjon med hantavirus og overføres ved kontakt med smågnagere. I likhet med leptospirose kan nephropathia epidemica gi smerter, men disse er oftest lokalisert i mage eller rygg (1). Inkubasjonstiden er imidlertid vanligvis minst en uke, noe som gjorde at hantavirusinfeksjon var mindre sannsynlig i dette tilfellet. Muskelsmerter i kombinasjon med feber og trombocytopeni er også typisk for human granulocytær ehrlichiose, en flåttbåren bakteriell infeksjon (2). Denne sykdommen ses imidlertid svært sjelden i Norge, og dessuten hadde vår pasient ikke observert noe flåttbitt.

På grunn av reiseanamnesen var infeksjon med Rickettsia også aktuell som differensialdiagnose. Rickettsioser kjennetegnes av myalgier, sterk hodepine, feber og eksantem. Både gastrointestinale symptomer og påvirkning av nyre- og leverfunksjon kan forekomme ved denne gruppen infeksjoner, og eksantem kan mangle (3). Anamnesen og sykdomsbildet var allikevel mest typisk for leptospirose. Da pasienten var i bedring, ble intravenøs antibiotikabehandling avsluttet og man startet med doksycyklintabletter. Pasienten hadde snakket med en slektning, som også hadde vært aktiv roer. Hun mente at pasienten kunne ha Weils sykdom, som hun selv hadde vært rammet av tidligere. Weils sykdom er navnet på den alvorlige formen av leptospirose. Feber, hodepine og myalgier er de vanligste symptomene 
ved denne formen, men hos 3-10\% av pasientene ses en initial septisk fase, hvor leverog nyrepåvirkning ikke er uvanlig.

Fjerde dag etter innleggelse var pasientens tilstand mye bedre. Smertene $i$ lårene var nesten helt borte og allmenntilstanden var god. CRP hadde falt til 45, trombocytter hadde steget til 89 og estimert GFR var 49. Leverenzymer var fortsatt stigende. Pasienten ble utskrevet til hjemmet med videre doksycyklinbehandling. Ved blodprøvekontroll etter noen dager var CRP 3 og leverenzymer og nyrefunksjonsprøver nærmest normalisert. Ved poliklinisk undersøkelse en uke etter utskrivning var pasienten i fin form og uten symptomer. Diagnosen ble bekreftet med positiv leptospiroseserologi. Antibiotikakuren ble avsluttet sju dager etter utskrivning. Ved oppfølging per telefon beskrev pasienten at han i løpet av få uker var tilbake $i$ vanlig form og startet opp igjen med roing og annen trening.

\section{Diskusjon}

Leptospirose er betegnelsen på en gruppe zoonoser forårsaket av bakterien Leptospira interrogans, som er beslektet med spiroketer (4). Navnet henspeiler på bakteriens utseende: leptos betyr smal eller fin, mens speira er det greske ordet for spiral. Inkubasjonstiden ved leptospirose er 2-20 dager, og i de fleste tilfeller har infeksjonen et subklinisk eller mildt, influensaliknende forløp. Feber, hodepine og myalgier er vanlige symptomer, mens buksmerter, konjunktivitt og eksantem forekommer sjeldnere. Ved septiske forløp ses også lever- og nyrepåvirkning, meningitt eller encefalitt, myokarditt og pulmonale symptomer som hoste og dyspné. Den septiske fasen kan vare opptil en uke. Uten behandling avtar feberen ofte etter en uke, men noen får tilbakefall med feber etter ytterligere 1-2 uker. En del av organsymptomene ved sykdommen skyldes sannsynligvis immunologiske responser på infeksjonen. Ved alvorlige forløp er trombocytopeni, leukocytose med neutrofili, ikterus og mikroskopisk hematuri vanlig (3). Hypokalemi og hyponatremi ses ofte og skyldes sannsynligvis bakteriens evne til å hemme aktiv $\mathrm{Na}-\mathrm{K}$ Cl-kotransport i oppadgående Henles sløyfe i nyrene $(5,6)$. Elektrolyttforstyrrelsene kan forverres av diaré og nyresvikt. Mortalitet ved alvorlig leptospirose er ca. $10 \%$, selv med adekvat antibiotisk behandling $(3,7)$.

Selv om kombinasjon av reiseanamnese, symptomer og kliniske funn kan gi mistanke om leptospirose, er flere andre infeksjonssykdommer aktuelle som differensialdiagnoser. Ved mildere sykdomsformer kan leptospirose forveksles med influensa eller liknende virusinfeksjoner. I vår kasuistikk var nephropathia epidemica en aktuell differensialdiagnose, mens human granulocytær ehrlichiose og rickettsioser var mye mindre sannsynlig. Kliniske funn ved denguefeber kan også likne leptospirose, men kort inku-

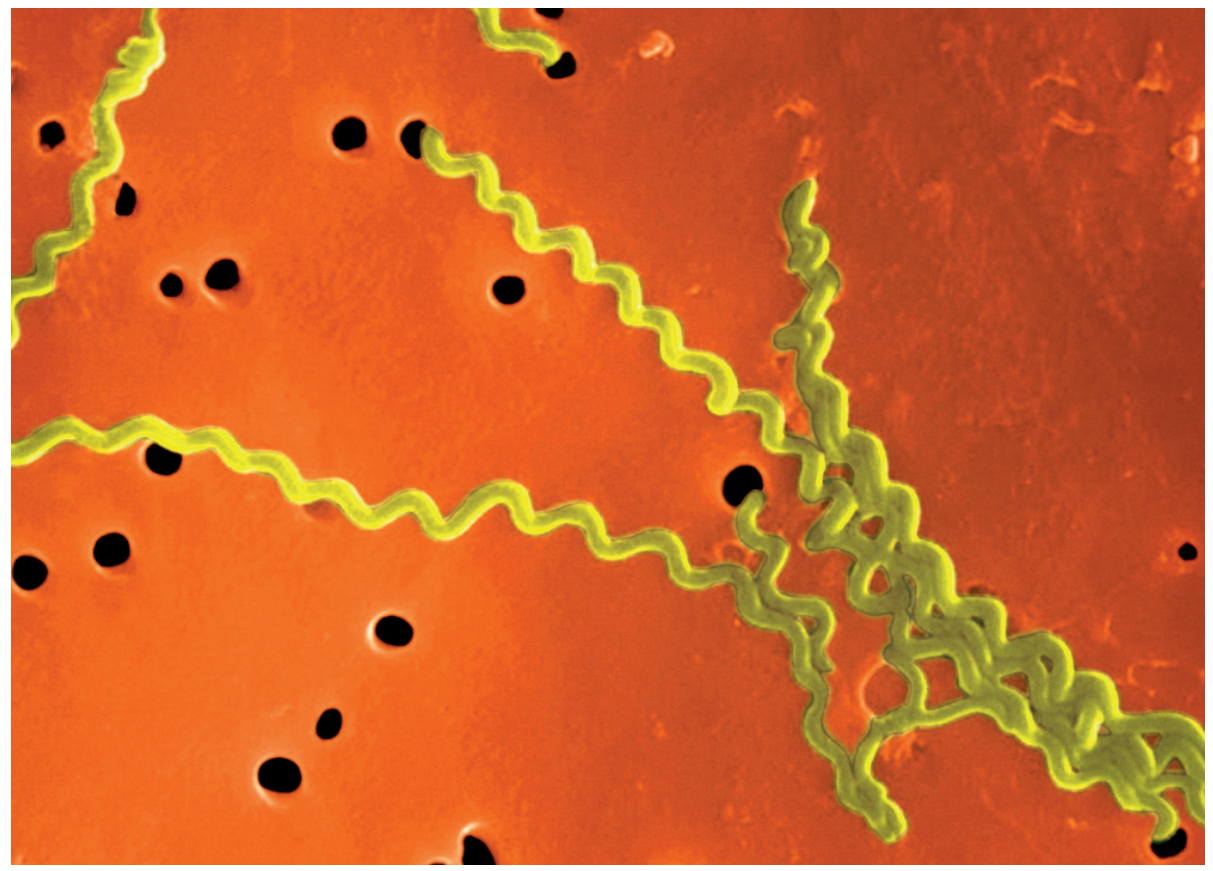

Figur 1 Leptospira interrogans. Elektronmikroskopi. Foto T. Carvalho/Visuals Unlimited/Corbis/Scanpix

basjonstid og reisemålet utelukket denne sykdommen hos vår pasient. Med forhøyede leverprøver kunne viral hepatitt ha vært en annen mulighet. Særlig ved hepatitt A forekommer feber og muskelverk i den preikteriske fasen.

I dette tilfellet var pasientens reiseanamnese allikevel typisk og sykdomsbildet klassisk for alvorlig leptospirose, Weils sykdom, og diagnosen ble bekreftet med positiv serologi. Serologisk undersøkelse er viktigste hjelpemiddel for å stille diagnosen leptospirose. I Norge gjøres leptospiroseserologi ved Folkehelseinstituttet. Testen som brukes der påviser både IgM og IgG. Sensitiviteten og spesifisiteten er over $95 \%$, og positiv prediktiv verdi er $90 \%$ for påvisning av akutt leptospirose (8). Leptospirose kan også diagnostiseres ved påvisning av bakterien i dyrking fra blod, urin, spinalvæske eller andre kroppsvæsker på spesialmedium. Særlig i den akutte septiske fasen kan Leptospira påvises i blod. Da dyrking oftest krever spesialmedium, må mistanken fremgå av henvisningen til laboratoriet. Bakterien vokser langsomt og det kan ta flere uker før den kan påvises ved dyrking (3). Hos vår pasient ble det ikke påvist Leptospira i urineller blodkulturer tatt ved innleggelse. Dette kan skyldes at det ikke ble bedt om dyrking på spesialmedium, eller at mikroben ikke lenger fantes i pasientens blod eller urin.

Når det gjelder behandling, mangler tilstrekkelig vitenskapelig kunnskapsgrunnlag for å lage klare retningslinjer for antibiotikavalg. Både penicillin, ampicillin, doksycyklin og ceftriakson ser ut til å ha god effekt, så lenge behandling startes tidlig i forløpet (9). Dersom man hos vår pasient hadde mistenkt leptospirose allerede ved innleggelsen, ville et smalspektret antibiotikum med mindre potensial for resistensutvikling, som penicillin, sannsynligvis vært førstevalg. Men også behandling med ceftriakson ga rask bedring av tilstanden.

I Norge er leptospirose først og fremst aktuell som importsykdom hos personer som har vært i kontakt med ferskvann forurenset med infisert dyreurin. Bakterien kan overleve i flere måneder i vann og fuktig jord. Den kan penetrere hud eller overføres ved at forurenset vann svelges eller kommer i kontakt med sår, for eksempel ved bading, roing og annen vannsport. Rotter er sannsynligvis hyppigste smittekilde, men også hunder, gris, storfe, hest og pinnsvin kan være reservoar for enkelte serotyper (4). Menn ser ut til å være mer utsatt for smitte enn kvinner (10). Bakterien har sin utbredelse i hele verden, men forekommer hyppigst i tropiske områder (3). Imidlertid er leptospirose påvist hos hund $\mathrm{i}$ Norge i løpet av de siste årene, et tegn på at bakterien forekommer også her til lands (4). Da påvisning krever spesialmedium og prøver sjelden tas uten mistanke om importsykdom, kan det tenkes at det også i Norge finnes udiagnostiserte sykdomstilfeller. God effekt av antibiotika som ofte gis ved uklare infeksjonstilstander kan også bidra til at prevalensen er underestimert.

Pasientens slektning (og avdelingens infeksjonsleger) hadde altså rett. Vår pasient ble sannsynligvis smittet i forbindelse med roing på ferskvann i Sør-Frankrike 1-2 uker før innleggelse, og såret på høyre albue kan ha vært inngangsport for mikroben. Ved mildere forløp er diagnosen vanskeligere å stille. Ved alvorlige influensaliknende symptomer hos personer som har vært eksponert for ferskvann i endemiske områder siste dager til uker, bør man ta prøver med tanke på leptospirose og starte behandling på mistanke.

Pasienten har gitt samtykke til at artikkelen blir publisert.

$$
\text { >> }
$$




\section{Marius Myrstad (f. 1978)}

er lege i spesialisering $\mathrm{i}$ indremedisin og geriatri ved Medisinsk avdeling, Diakonhjemmet

Sykehus i Oslo.

Ingen oppgitte interesssekonflikter.

\section{Kiarash Tazmini (f. 1976)}

er lege i spesialisering ved medisinsk avdeling, Diakonhjemmet sykehus.

Ingen oppgitte interesssekonflikter.

\section{Knut H. Spæren (f. 1969)}

er spesialist i indremedisin og infeksjonsmedisin, med diplom som ledende revisor. Han er overlege ved medisinsk avdeling og smittevernoverlege ved Diakonhjemmet Sykehus og medlem i den nasjonale matsmittekomiteen.

Ingen oppgitte interesssekonflikter.

\section{Aira Bucher (f. 1949)}

er spesialist i infeksjonssykdommer og avde-

lingssjef og -overlege ved Medisinsk avdeling Diakonhjemmet Sykehus i Oslo.

Ingen oppgitte interessekonflikter.

\section{Litteratur}

1. Norrlänska infektionssjukdomar. I: Iwarson S, Norrby R, red. Infektionsmedicin. Epidemiologi, klinik, terapi. Sävedalen: Säve förlag, 2007: $370-81$

2. Kristiansen BE, Jenkins A, Tveten $Y$ et al. Human granulocytær ehrlichiose i Norge. Tidsskr Nor Lægeforen 2001; 121: 805-6.

3. Icke inhemska bakteriella infektioner. I: Iwarson $\mathrm{S}$, Norrby R, red. Infektionsmedicin. Epidemiologi, klinik, terapi. Sävedalen: Säve förlag, 2007 382-93.

4. Leptospirose. I: Smittevernhåndboka. 3. utg. Oslo Nasjonalt folkehelseinstitutt, 2005: 98.

5. Wu MS, Yang CW, Pan MJ et al. Reduced renal $\mathrm{Na}+-\mathrm{K}+-\mathrm{Cl}-\mathrm{co}$-transporter activity and inhibited
NKCC2 mRNA expression by Leptospira shermani: from bed-side to bench. Nephrol Dial Transplant 2004; 19: 2472-9

6. Krishnan A, Karnad DR, Medhekar TP. Paralysis due to renal potassium wasting: an unusual presentation of leptospirosis. Nephrol Dial Transplant 2003; 18: 2454-5

7. Senior K. Leptospirosis and Weil's syndrome: cause for concern? Lancet Infect Dis 2010; 10: $823-4$

8. Serion Elisa classic. Leptospira IgG/lgM. www. virion-serion.com/71.0.html?\& L=1 (27.3.2011).

9. Bharti AR, Nally JE, Ricaldi JN et al; Peru-United States Leptospirosis Consortium. Leptospirosis: a zoonotic disease of global importance. Lancet Infect Dis 2003; 3: 757-71.

10. Scott G, Coleman TJ. Leptospirosis. I: Gordon CC Alimuddin Z, red. Manson `s Tropical Diseases. 21. utg. London: Saunders, 2003: 1165-70.

Mottatt 23.11. 2010, første revisjon innsendt 5.4 2011, godkjent 10.11. 2011. Medisinsk redaktør Are Brean.

\section{Kommentar}

\section{Turisme, klimaendringer og diagnostikk}

Reisevirksomhet og klima er viktige faktorer for spredning av en rekke infeksjonssykdommer. Den globale oppvarmingen og økende nedbør gir bedrede vilkår for økt spredning av mange sykdommer som overføres via mygg, andre insekter og dyr. Dette gjør at også reiser innen Europa kan medføre sykdommer som vi vanligvis ikke tenker på hvis ikke pasienten har vært i varmere og fjernere strøk. Flere av disse sykdommene er derfor underdiagnostisert, dels fordi vi ikke tenker på dem og dels fordi diagnostikken krever spesialundersøkelser $(1,2)$.

Siden 2007 er det rapportert kolerasmitte i Frankrike, spredning av Chikungunyafeber i Italia, malaria i Italia og Hellas og denguefeber i Sør-Frankrike. Allerede i 1960 etablerte vestnilfeber seg i Romania, og har derfra i flere omganger spredd seg til andre europeiske land via fugl og mygg som vektorkjede (2). Leptospiroseutbrudd har vært knyttet til oversvømmelser, og er rapportert fra en rekke europeiske land i tillegg til utviklingsland $(1,3-6)$.

Flere av disse sykdommene krever spesifikke målrettede diagnostiske tiltak før diagnosen kan bekreftes. Ofte legges pasientene inn med mistanke om sepsis (septikemi) og diagnosen forsøkes bekreftet ved hjelp av blodkulturer. Den kanskje viktigste årsaken til at man ikke får bekreftet diagnosen er at pasienten har fătt antibiotika før innleggelsen. Men ved en del infeksjoner, som f. eks. leptospirose, brucellose og tularemi, vil bakteriene uansett vokse dårlig i vanlig blodkultur. Noen krever lengre inkubasjonstid enn de fem døgn som er vanlig, noen krever spesialmedier. Andre sykdommer kan lettest påvises ved spesifikke serologiske prøver og polymerasekjedereaksjonstest (PCR) (4).
Diagnostikken er derfor avhengig av gode kunnskaper og kjennskap til hvilke muligheter som foreligger. Mikrobiologiske avdelinger vil, hvis de får gode opplysninger, selv kunne sette opp spesialanalyser. I andre tilfeller må spesialanalyser rekvireres. Det blir derfor viktig å ta opp en god anamnese - hvor har du vært og når, og hva har du gjort?

Diagnostikken ved «importfeber» er viktig fordi flere av de aktuelle diagnosene krever spesifikk behandling. Dette gjelder for eksempel tyfoidfeber, rickettsioser og malaria, hvor vanlig antibiotikabehandling ofte ikke virker.

Leptospirose er den vanligste bakterielle zoonosen. Den fremkalles av flere patogene stammer som kan ha ulike gnagere og enkelte andre dyr som asymptomatiske bærere. Regn og oversvømmelse er viktige faktorer for spredning av Leptospira. Vannet blir infisert fra kroniske bærere blant rotter og andre gnagere som skiller ut Leptospira i urinen. Bakterien kan under gunstige forhold overleve i mange måneder i vann.

Det har vært en betydelig økning i forekomsten blant turister, spesielt i forbindelse med sportslige aktiviteter knyttet til vann som $\mathrm{f}$. eks rafting, triatlon, roing og annen vannsport (3-5). I likhet med flere andre eksotiske sykdommer kan sykdomsbildet variere. Dette er derfor en viktig diagnostisk mulighet ved «importfeber». De aller fleste tilfeller av leptospirose er milde febersykdommer som forblir udiagnostisert, men anslagsvis $10 \%$ får et alvorlig sykdomsbilde med betydelig mortalitet (6). Sykdommen antas å gi flest dødsfall blant fattige i utviklingsland, som infiseres på grunn av stor smittefare og dårlige behandlingsmuligheter.

\section{Johan N. Bruun}

j.n.bruun@medisin.uio.no

Infeksjonsmedisinsk seksjon

Universitetssykehuset Nord-Norge

og

Universitetet i Tromsø

Johan N. Bruun (f. 1936) er pensjonert overlege og professor fra Ullevål universitetssykehus og Universitetet i Oslo. Han er overlege ved Infeksjonsmedisinsk seksjon, Universitetssykehuset Nord-Norge, Troms $\varnothing$ og professor ved Universitetet i Troms $\varnothing$.

Forfatter har fylt ut ICMJE-skjemaet og oppgir ingen interessekonflikter.

Litteratur

1. Victoriano AF, Smythe LD, Gloriani-Barzaga N et al. Leptospirosis in the Asia Pacific region. BMC Infect Dis 2009; 9: 147

2. Bezirtzoglou C, Dekas K, Charvalos E. Climate changes, environment and infection: Facts, scenarios and growing awareness from the public health community within Europe. Anaerobe 2011; 17 337-40.

3. Monahan AM, Miller IS, Nally JE. Leptospirosis: risks during recreational activities. J Appl Microbiol 2009; 107: 707-16.

4. Lau C, Smythe L, Weinstein P. Leptospirosis: an emerging disease in travellers. Travel Med Infect Dis 2010; 8: 33-9

5. Pappas G, Papadimitriou P, Siozopoulou V et al. The globalization of leptospirosis: worldwide incidence trends. Int J Infect Dis 2008; 12: 351-7.

6. Hartskeerl RA, Collares-Pereira M, Ellis WA Emergence, control and re-emerging leptospirosis: dynamics of infection in the changing world. Clin Microbiol Infect 2011; 17: 494-501. 